\title{
Analysis Support Families With Quality Of Life After Stroke Patients
}

\author{
Heri Saputro*, Mariana Ina Camo, Budi Suraksono, Sri Kardjati \\ Nursing Departement, STRADA Indonesia Institute of Health Sciences, Indonesia \\ *h.saputro@iik-strada.ac.id
}

\begin{abstract}
Post-stroke decreased ability and function of organs so that they are unable to meet their daily needs independently. Family support is needed in that phase in order to increase confidence and motivation. The purpose of this study to determine the relationship of family support and quality of life of patients post-stroke neurological poly Karsa Husada Hospital Batu. The study design was cross-sectional descriptive correlative approach. Data collection tool is a questionnaire guide. Sample of 35 respondents using accidental sampling technique. The independent variable in this study is the family support and the dependent variable quality of life of patients with post-stroke. Data were analyzed statistically using the Spearman Rho with $\alpha=0.05$. The results showed 16 respondents, or $45.8 \%$ of respondents received sufficient family support. Respondents who have a sufficient quality of life amounted to 15 respondents or $42.7 \%$. By Spearman Rho obtained significance value ( $p$ value $=0.00)<(\alpha=0.05)$, which proved to be no family support relationships with the quality of life of the elderly after a stroke in neurological poly Karsa Husada Hospital Batu. Post-stroke patients have problems of physical health, psychological, level of dependence, social relationships, environment and personal beliefs. Therefore, they need emotional support, awards, instrumental and information, especially of the family as the people closest to them thus improving patient quality of life after stroke.
\end{abstract}

Keywords: Family Support, Quality Of Life, Patients With Post-Stroke 


\section{STRADA Jurnal Ilmiah Kesehatan}

DOI: $10.30994 /$ sjik.v8i2.219

\section{BACKGROUND}

Stroke is the third leading cause of death in the world after coronary heart disease and cancer in both developed and developing countries. One in 10 deaths is caused by a stroke. Globally 15 million people get strokes every year, one third die and the rest experience permanent disability (Stroke forum, 2015). Stroke is a leading cause of disability that can be prevented (American Heart Association, 2014).

Basic Health Research (2013) reports the prevalence of stroke in Indonesia based on the highest diagnosis of health in North Sulawesi (10.8 "), followed by DI Yogyakarta (10.3"), Bangka Belitung and DKI Jakarta at 9.7 per mile, respectively. The prevalence of stroke in North Sumatra reaches $10.3 \%$. Riskesdas 2013 data shows that the prevalence of stroke in Indonesia based on the diagnosis of health workers was found to be 7.0 per mile and that based on the diagnosis of health workers or symptoms was 12.1 per mile. So, as many as $57.9 \%$ of stroke have been diagnosed by health workers. The prevalence of stroke is based on the highest diagnosis of health workers in North Sulawesi $(10.8 \%)$, followed by Yogyakarta (10.3\%), Bangka Belitung and DKI Jakarta at 9.7 per mile. The highest prevalence of stroke based on diagnosis by health professionals and symptoms was in South Sulawesi (17.9\%), DI Yogyakarta (16.9\%), Central Sulawesi (16.6\%), followed by East Java at 16 per mile (Riskesdas, 2013) .

Stroke management is generally divided into two stages. The acute stage and the post acute stage or the recovery stage. The treatment goals are focused on rehabilitation, prevention of complications and recurring strokes (National Institute of Neurological Disorder and Stroke in Yuniarsih, 2011).

The patient's own family plays a big role in the recovery phase, so from the beginning of the family care is expected to be involved in the handling of stroke patients. The low motivation and hope for recovery of sufferers and the lack of family support has the potential to cause burdens and lead to stress (Wulandari, 2016).

Some things that become the role of the family for post-stroke patients according to (Yaslina, 2011) are providing support and also attention to the recovery of patient health, as well as in terms of sending patients to control and also reminding when taking medication, other than that patients with stroke because the disability often falls into depression, assistance and full support from the family and the enthusiasm of the family will greatly help recovery, assist patients in carrying out daily activities, and provide assistance if necessary, carry out routine blood pressure control, at least within a week once due to stroke risk factors is an increase in high blood pressure / hypertension.

Control of blood pressure and cholesterol is the key to preventing future stroke or recurrent strokes (Muttaqin, 2008).

The preliminary study was carried out by looking at registers and RM documents as well as direct interviews with the head of the clinic, the nursing nurse and physiotherapist in the nerve clinic as well as direct observation. From the data of stroke patients who visited or sought treatment to nerve poly in 2014 the number of sufferers was 961 patients, in 2015 there were 1294 patients and in 2016 there were 1405 patients. From these data, 80\% experience impaired mobility / immobilization, (medical record at Karsa Husada Batu Public Hospital, 2017), where the patient needs further treatment.

Of these, $95 \%$ of them visited poly, accompanied by family, both children, wife / husband, and other family members. The officer also said that the ability, care, education and background of each family member differ from one another. Because family support is 


\section{STRADA Jurnal Ilmiah Kesehatan}

DOI: $10.30994 /$ sjik.v8i2.219

absolutely necessary for patients after stroke at home because of the high level of dependence on other family members.

Based on data showing that stroke sufferers in Karsa Husada Batu Public Hospital in particular are increasing, where the most dominant result of stroke is physical mobility problems, as well as the diverse roles of their families as caregivers, where one of the functions of the family is as a health nurse for family members who another, the authors are interested in researching "analysis of family support with the quality of life of post-stroke patients in the Neurology Clinic of Karsa Husada General Hospital, Batu City".

\section{OBJECTIVE}

Knowing the relationship between family support and the quality of life of post-stroke patients in the neural poly at Karsa Husada Batu Public Hospital.

\section{METHODS}

The research design used is the correlation study, which is a study that involves the act of collecting data to determine whether there is a relationship and the level of relationship between two or more variables. This research is conducted, when we want to know about the presence or absence and strength of the relationship of variables related to an object or subject under study so that researchers will be able to develop it in accordance with the research objectives.

With a quantitative approach using a cross sectional design, which aims to analyze the relationship between family support and the quality of life of patients after a physical stroke in the Nerve Poly Karsa Husada Batu Hospital. Batu from the 2nd to the 14th of October 2017 and 35 samples were obtained during the study.

\section{RESULTS}

From the results of the study it can be seen that of the 35 respondents most of them have sufficient support for the quality of life of post-stroke patients by 14 respondents (40\%).

Statistical analysis test results between family support and quality of life of post-stroke patients at the nerve poly at Karsa Husada Batu Public Hospital using Spearman's rho.

\begin{tabular}{cllrr}
\hline \multicolumn{3}{c}{ Correlations } \\
\hline \multirow{2}{*}{$\begin{array}{c}\text { Spearman's } \\
\text { rho }\end{array}$} & Family & Correlation Coefficient & Family Support & Quality of Life \\
\cline { 3 - 5 } & Support & Sig. (2-tailed) & 1.000 & $.862^{* *}$ \\
& & $\mathrm{~N}$ &. & .000 \\
\cline { 2 - 6 } & Quality of & Correlation Coefficient & 20 & 20 \\
& Life & Sig. (2-tailed) & $.862^{* *}$ & 1.000 \\
& & $\mathrm{~N}$ & .000 & 20 \\
\hline
\end{tabular}

**. Correlation is significant at the 0.01 level (2-tailed).

From the statistical data of Spearman 's rho obtained a significance level of 0,000 , so 0,000 $<0.05$ which means there is a relationship between family support and quality of life of patients after stroke.

From the results above it can be seen that the coefficient between family support and quality of life for post-stroke patients is 0.862 (positive sign). This means that the higher the family support the higher the quality of life of patients after stroke 


\section{STRADA Jurnal Ilmiah Kesehatan}

DOI: $10.30994 /$ sjik.v8i2.219

\section{DISCUSSION}

Family Support in Post-Stroke Patients

It can be seen that from 35 respondents, 16 respondents (45.8\%) were sufficient. The results of this study obtained all components of family support in post-stroke patients including emotional, informational, instrumental and appreciation support showed that the support obtained was sufficient. This is assumed because the family still loves and respects their family members who have had a stroke, hopes for healing and still wants to enjoy life with them even when they are sick.

Quality of Life for Post-Stroke Patients

The results showed that post-stroke patients in the nerve nerve of RSU Karsa Husada Batu had a sufficient quality of life that is equal to 15 respondents or $42.7 \%$. Stroke can cause motor paralysis, resulting in patients needing help from others to carry out daily activities.

Besides the disturbance of the function of the atmosphere of feeling and behavior. This sometimes causes patients to feel useless anymore because of the many limitations that exist in him due to his illness. In this case the family can be a dependent place for family members who have stroke so that the value of the level of dependency is sufficient. Families are aware that caring for sick family members is a form of reciprocation and a manifestation of their love, and makes the pious field they will receive. Conversely, if they treat their family members badly it will be worth sin.

Post-stroke sufferers' social activities are reduced even some have never left the house to take part in community social activities. Post-stroke sufferers mostly from rural areas whose social life is still close to their citizens. Because the pain causes disruption of self-concept and limited physical activity causes patients to withdraw and disrupt their social relationships. From the aspect of dependence and spirituality, religion and personal beliefs of research are of sufficient value, because the patient is at the acceptance stage. They realize that whatever situation is happening to them is solely due to trials from God, so that their daily time is used to worship a lot. Not much more of the worldly things they wish for and the rest of their lives are mostly used for spiritual and religious needs.

Relationship between Family Support and Quality of Life of Post-Stroke Patients

Statistical analysis test results between family support for the quality of life of patients after stroke in the Knee Husada Batu hospital nerve using Spearman's rho obtained a correlation coefficient of 0.862 while the significance value was $0.00<(\alpha \leq 0.05)$, which means there is a relationship between family support on the quality of life of patients after stroke. Therefore, support from the closest people, especially their families, will be needed and will influence them in their care and recovery process. The higher the support from the family provided, the better the quality of life of patients after stroke.

\section{CONCLUSION}

There is a relationship between family support for the quality of life of patients after stroke in the nerve nerve of Karsa Husada Batu Hospital with a positive relationship so that the higher the family support the higher the quality of life of patients after stroke. 


\section{STRADA Jurnal Ilmiah Kesehatan}

DOI: $10.30994 /$ sjik.v8i2.219

\section{REFERENCES}

Brillianti, Pretty Angelina. (2016). Hubungan Self-Management Dengan Kualitas Hidup PasienPascastroke Di Wilayah Puskesmas Pisangan Ciputat. Skripsi. Jakarta : Fakultas Kedokteran Dan Ilmu Kesehatan Universitas Islam Negeri Syarif Hidayatullah

Faturochman, Tri Hayuning Tyas, Wenty Marina Minza \& Galang Lufityanto Elizabeth J. Corwin. ( 2011) Asuhan Keperawatan Kardiovaskuler. Edisi V. Jakarta : Penerbit buku kedokteran EGC

Friedman, M.M., Bowden, V.R., \& Jones, E.G. (2010). Buku ajar keperawatan keluarga: Riset, teori, dan praktik, alih bahasa, Akhir Yani S. Hamid dkk; Ed 5. Jakarta : EGC

Ghozali, Imam. (2009). Aplikasi Analisis Multivariate Dengan Program SPSS, Edisi Keempat. Jakarta : Penerbit PT. Bhuana Ilmu Populer.

Kementrian Kesehatan, R.I. (2013). Riset Kesehatan Dasar : Riskesdas 2013. Jakarta : Badan Penelitian Dan Pengembangan Kesehatan.

Nofitri. (2009). "Kualitas Hidup Penduduk Dewasa di Jakarta". (http://www.lontar.ui.ac.id) Diakses tanggal 11 Maret 2017

Notoatmodjo. (2010). Promosi Kesehatan Teori dan Aplikasi. Jakarta : Rineka Cipta

Nursalam. (2008). Konsep dan Penerapan Metodologi Penelitian Ilmu Keperawatan: Pedoman Skripsi, Tesis, dan Instrumen Penelitian Keperawatan Edisi 2. Jakarta : Salemba Medika

Purwanti, Okti S dan Maliya, A. (2008).Rehabilitasi Pasca Stroke, Jurnal berita Ilmu Keperawatan.Vol. 1, No. 1, Maret 2008: 43

Sekarwiri. ( 2008). "Metode penelitian dan uji realibiltas dan validitas WHOQoLREF".(http://www.lontar.ui.ac.id/file?file=pdf/abstrak-94781.pdf)diakses 15 Maret 2017

Smeltzer And Bare. (2008). Textbook of Medical Surgical Nursing Vol.2. Philadelphia : Linppincott William \& Wilkins.

Yani, Fitri Eka. (2010). Perbedaan Skor Kualitas Hidup Terkait Kesehatan Antara Pasien Stroke Iskemik Serangan Pertama dan berulang. Skripsi. Surakarta : Fakultas Kedokteran Universitas Sebelas Maret

Yaslina. (2011). Hubungan Dukungan Keluarga, Program Pemulangan Dari Rumah Sakit Dan Karakteristik Klien Dengan Perawatan Di Rumah Pada Perawatan Di Rumah Pada Aggregate Dewasa Pasca Stroke

Kota Bukittinggi. Tesis.Depok : FIK Universitas Indonesia

Yastroki, 2012 . Stroke Penyebab Kematian Urutan Pertama di Rumah Sakit Indonesia. (http://www.yastroki.or.id). Diakses tanggal 15 Maret 2017

Yusra, Aini. (2011). Hubungan Antara Dukungan Keluarga DenganKualitas Hidup Pasien Diabetes Melitus Tipe 2 Di Poliklinik Penyakit Dalam Rumah Sakit Umum Pusat Fatmawati Jakarta. Tesis. Jakarta : FIK Universitas Indonesia 